\title{
Model Work Engagement Angkatan Kerja Generasi Millennial dengan Meaningful Work sebagai Mediator
}

\author{
Rina Mulyati, ${ }^{1,2}$, Fathul Himam 2,2, Bagus Riyono ${ }^{2}$ E Fendy Suhariadi ${ }^{3}$ \\ ${ }^{1}$ Fakultas Psikologi dan Ilmu Sosial Budaya Universitas Islam Indonesia, ${ }^{2}$ Fakultas Psikologi \\ Universitas Gadjah Mada, ${ }^{3}$ Fakultas Psikologi Universitas Airlangga
}

\begin{abstract}
Key success for organization with millennial workforce to win the competitiveness on business industry in 4.0 era is having a compatible model of work engagement. In 2025, millennials will dominate up to $75 \%$ of the labour force. Therefore it is necessary to scientifically inquire deeper on this generation. This research adopted Job Demand Resources Model (JD-R) as theoretical framework. It specifically aimed to analyse the most suitable work engagement model among millennials who work at state owned companies. Predictor variables in this research were job crafting and meaningful work as mediator. This quantitative research ( $\mathrm{N}=318$ ) used scaling for data collection and Structural Equation Model (SEM) to test the data. This research found: 1) work engagement model fits for the millennial workforce, 2) job crafting has direct significant effect to work engagement, and 3) meaningful work plays as mediator between job crafting and work engagement.
\end{abstract}

Keywords : job crafting; meaningful work; millennial workforce; work engagement

\begin{abstract}
Abstrak. Model work engagement yang paling kompatibel untuk angkatan kerja generasi millennial menjadi kunci keberhasilan organisasi dalam memenangkan dunia bisnis yang sangat kompetitif di era industri 4.0. Angkatan kerja generasi millennial akan mendominasi dunia kerja sampai 75\%. mulai tahun 2020. Menggunakan kerangka teoritis Model JobDemands-Resources (JD-R), penelitian ini secara spesifik bertujuan menguji model work engagement yang paling cocok bagi angkatan kerja generasi millennial yang bekerja di BUMN dengan melibatkan variabel job crafting sebagai variabel prediktor dan variabel meaningful work sebagai mediator. Artikel ini merupakan bagian dari penelitian disertasi, menggunakan pendekatan kuantitatif dengan karyawan BUMN sebagai responden penelitian. Hasil analisis Model Persamaan Struktural menunjukkan bahwa 1) model work engagement yang ditawarkan untuk angkatan kerja generasi millennial terbukti fit, 2) meaningful work memberikan pengaruh langsung secara kuat terhadap work engagement 3) meaningful work berperan sebagai mediator untuk hubungan job crafting dengan work engagement.
\end{abstract}

Kata kunci : generasi milenial; kebermaknaan kerja; keterikatan kerja; rekayasa pekerjaan

Dihadapkan pada rendahnya tingkat work engagement karyawan angkatan kerja generasi millennial di berbagai belahan dunia (Akhavan Sarraf, Abzari, Nasr Isfahani, \& Fathi, 2017; Chawla, Dokadia, \& Rai, 2017; Kiiru-Weatherly, 2016; Rigoni

\footnotetext{
${ }^{1}$ Korespondensi mengenai isi artikel ini dapat dilakukan melalui rinamulyati@uii.ac.id

2 atau melalui fathulpsi@ugm.ac.id
} 
\& Nelson, 2016), termasuk generasi millennial di Indonesia (Alexander \& Mulyati, 2017; Mulyati, Himam, Riyono \& Suhariadi, 2018; Munfaridah, Mulyati \& Kurniawan, 2018), maka menemukan model desain kerja yang paling fit bagi tenaga kerja generasi millennial menjadi sangat penting bagi organisasi untuk mendapatkan level work engagement paling tinggi.

Ketersediaan model work engagement untuk angkatan kerja generasi millennial berpeluang menjadikannya sebagai kerangka intervensi yang paling valid secara ekologis. Identifikasi berbagai tuntutan kerja dan sumber daya pekerjaan pada kelompok demografis, jenis pekerjaan dan sektor industri tertentu dapat meningkatkan efektivitas intervensi work engagement di kelompok tersebut (Bakker \& Albrecht, 2018).

Urgensi tersedianya model teoretis desain kerja yang paling kompatibel dengan karakteristik dominan generasi millennial terkait pekerjaan juga diperkuat oleh latar belakang lingkungan sosial dan politik yang terpecah-pecah dan perubahan besar yang didorong oleh Era Revolusi Industri Keempat. Era ini secara signifikan sedang mengubah model-model bisnis di semua sektor di seluruh dunia. Perubahan yang terjadi diantaranya adalah orang dipaksa berpindah dari pekerjaan yang selama ini digelutinya (job displacement) dan job creation, yaitu penciptaan berbagai pekerjaan baru (World Economic Forum, 2017).

Desain kerja memengaruhi bagaimana seorang karyawan menyelesaikan pekerjaan dan cara mereka mendapatkan pengalaman terkait penyelesaian pekerjaannya (Grant, Fried, \& Juillerat, 2010). Salah satu teori desain kerja yang paling sering digunakan untuk menjelaskan work engagement adalah Teori Job-Demands-Resources atau disingkat menjadi JD-R Theory. Teori yang merupakan perluasan dari Job Characteristic Model ini menegaskan bahwa work engagement karyawan dapat diprediksikan dari hasil kombinasi karakteristik pekerjaan, berupa sumber daya pekerjaan dengan karakteristik individu yang berupa sumber daya pribadi (Bakker \& Demerouti, 2014; Bakker \& Demerouti, 2017; Demerouti, Bakker, Nachreiner, \& Schaufeli, 2001).

Untuk memahami work engagement angkatan kerja generasi millennial yang bekerja di BUMN, peneliti memakai definisi work engagement sebagai sebuah keadaan jiwa yang positif dan bahagia terkait pekerjaan, ditandai oleh semangat, dedikasi, dan penghayatan (Schaufeli, Bakker, \& Salanova, 2006). Pengertian work engagement dalam konteks penelitian ini juga menggunakan proses motivasional model JD-R yang meyakini bahwa work engagement sebagai fungsi dari interaksi dua kelompok sumber daya yang memotivasi secara instrinsik. Sumber daya tersebut adalah sumber daya pekerjaan dan sumber daya pribadi. Kedua sumber daya tadi menjadi energi bagi setiap karyawan yang mendorong persistensi mereka dan membuat mereka fokus pada pekerjaan. Dalam bahasa lain, sumber daya yang dimiliki dapat mengembangkan engagement karyawan dalam hal energi, dedikasi dan konsentrasi yang pada gilirannya berdampak positif pada outcome seperti performansi kerja (Bakker, 2011; Bakker \& Demerouti, 2007, 2008; Demerouti et al., 2001).

Menurut teori JD-R, work engagement berpeluang terjadi ketika para karyawan 
dihadapkan pada tuntutan pekerjaan yang menantang sekaligus memiliki sumber daya yang memadai untuk berhasil mengatasi berbagai tantangan tersebut (Bakker \& Sanz-Vergel, 2013; Tadić, Bakker, \& Oerlemans, 2015). Singkat kata, teori JD-R menyatakan bahwa sumber daya pekerjaan secara langsung berhubungan positif dengan work engagement dan tuntutan pekerjaan yang menantang dapat memperkuat hubungan positif tersebut. Sebaliknya, tuntutan pekerjaan yang menghambat dapat melemahkan hubungan positif antara sumber daya pekerjaan dan work engagement (Bakker \& Demerouti, 2014; Bakker \& Demerouti, 2017; Demerouti, 2014).

Meskipun model JD-R disepakati sebagai kerangka kerja yang sangat bermanfaat untuk memahami work engagement, tetapi mekanisme psikologis yang menjelaskan bagaimana pengalaman terkait sumber daya berakibat pada peningkatan work engagement masih perlu dikaji. Proses-proses psikologis yang diasumsikan mendasari hubungan antara sumber daya kerja, sumber daya pribadi, dan work engagement belum sepenuhnya dieksplorasi dan diuji secara luas (Albrecht, 2013; Bakker, Albrecht, \& Leiter, 2011; Bakker \& Albrecht, 2018). Sejumlah perspektif teoretis mengusulkan bahwa proses-proses psikologis seperti merasa berkewajiban, merasa bermakna dan suasana hati positif sebagai sumber daya kerja yang pemenuhannya berakibat pada pengalaman work engagement karyawan.

Pengalaman bermakna dalam
bekerja secara psikologis akan menggerakkan sikap, perilaku dan kelekatan dengan pekerjaan yang pada akhirnya menjadi pendorong yang paling penting untuk work engagement (Albrecht, 2013; May, Gilson, \& Harter, 2004; Rothmann \& Olivier, 2007; Shuck \& Rose, 2013). Penelitian yang dilakukan oleh Nakamura \& Otsuka (2012) menunjukkan bahwa perusahaan yang mengembangkan meaningful work dapat meraih manfaat dengan terjadinya peningkatan keterlibatan karyawan dalam pekerjaannya.

Argumentasi penulis menjadikan meaningful work sebagai variabel mediator hubungan antara karakteristik pekerjaan (sumber daya pekerjaan, sumber daya personal) dan work engagement sebagaimana dijelaskan dalam model JDR, datang dari Job Characteristics Model (Hackman \& Oldham, 1976). Model ini menjelaskan tentang critical psychological states yang berperan sebagai mediator antara 3 karakteristik inti pekerjaan (task variety, task identity, task significance) dengan variabel outcome (job satisfaction, intrinsic motivation, work effectiveness). Kondisi psikologis yang penting ini salah satunya adalah meaningfulness of work. Pada model ini, pekerjaan dialami sebagai sesuatu yang bermakna dan dipercaya memiliki dampak positif terhadap orang lain. Perbaikan meaningful work berdampak positif terhadap work engagement karyawan di Jepang (Nakamura \& Otsuka, 2012). Meaningful work berkorelasi dengan komitmen kerja yang kuat dan keterlibatan secara instensif dalam pekerjaan (Steger, 2016).

Merujuk pada pendapat Albrecht (2013) dan Teori Determinasi Diri (Ryan \& Deci, 2000), peneliti mendefinisikan meaningful work angkatan kerja generasi millennial sebagai sebuah keadaan psikologis yang positif di mana mereka merasa dirinya berkontribusi secara 
positif, penting, dan berharga untuk sebuah tujuan besar melalui eksekusi pekerjaan mereka.

Perusahaan perlu memunculkan rasa kebermaknaan bagi karyawannya dengan menciptakan tujuan yang lebih tinggi yang menghasilkan nilai-nilai luhur (values) bagi seluruh pemangku kepentingan. Generasi millennial menganggap bahwa memperjuangkan tujuan organisasi lebih penting dari sekedar tujuan finansial. Mereka melihat keberhasilan finansial sebagai konsekuensi logis dari tercapainya tujuan organisasi secara benar dan lebih tepatnya terimplementasinya kebijakan organisasi terkait sumber daya manusia. (Lewis \& Yeoman, 2016).

Perubahan-perubahan dalam hal bagaimana pekerjaan diorganisasikan dan ditampilkan menuntut para pekerja untuk mengambil langkah-langkah tertentu yang berdampak terhadap kualitas pekerjaan mereka. Perilaku-perilaku proaktif yang adaptif dengan lingkungan kemungkinan menjadi kunci bagi setiap pekerja untuk mendapatkan kesesuaian antara kebutuhan-kemampuan dengan kesempatan-tuntutan di lingkungan kerjanya. Perubahan-perubahan yang dilakukan karyawan atas inisiatif sendiri dalam mendesain kembali cara mereka bekerja dikenal sebagai job crafting (Parker \& Collins, 2010; Strauss \& Parker, 2014; Tims \& Bakker, 2010; Wrzesniewski \& Dutton, 2001).

Job crafting menghadirkan kesempatan bagi angkatan kerja generasi millennial untuk mengintegrasikan dan mengorganisasikan pengalaman kerja mereka ke dalam sebuah rasa diri yang otentik. Job crafting merupakan upaya individu dalam menyelaraskan pengalaman kerja dengan dorongan internal yang berdampak pada berkembangnya motivasi yang lebih instrinsik. Khusus untuk angkatan kerja generasi millennial, mereka diharapkan terdorong untuk crafting pengalaman kerja mereka menjadi aktivitas yang memuaskan secara psikologis. Rekayasa dalam pekerjaan menjadi peluang bagi mereka untuk mendayagunakan bakat, disposisi dan preferensi kerja secara lebih baik. Hasil dari proses ini pada gilirannya menjadikan mereka mampu bersintesa dan berintegrasi dengan lingkungan kerja. Lebih jauh, upaya yang dilakukan dalam rangka memuaskan kebutuhan ini berpengaruh terhadap keberfungsian dan well-being mereka (Slemp \& VellaBrodrick, 2014).

Job crafting menjadi sangat penting khususnya ketika terjadi perubahan karakteristik, jenis dan lingkungan dalam dunia kerja. Ketika perubahan tersebut direspon dengan peluang melakukan job crafting, maka karyawan dapat memodifikasi lingkungan atau pekerjaan agar didapatkan kembali makna dalam pekerjaan.

Kebermaknaan dalam bekerja dianggap sebagai alasan penting individu melakukan job crafting. Hanya saja penelitian sebelumnya lebih banyak fokus pada luaran job crafting seperti work engagement, job performance, dan komitmen organisasi. Artinya cara job crafting memengaruhi work engagement karyawan melalui meaningful work belum diuji. Padahal penting untuk diteliti apakah para karyawan yang melakukan inisiatif untuk mengubah kualitas kerja juga akan meningkatkan kebermaknaan kerja yang kemudian berdampak pada work engagement optimal (Berg, Wrzesniewski, \& Dutton, 2010; Kira \& Balkin, 2014; Leana, 
Appelbaum, \& Shevchuk, 2009; Tims, Bakker, \& Derks, 2013).

Penelitian ini juga akan menguji secara empiris asumsi Wrzesniewski dan Dutton (2001) bahwa job crafting merupakan strategi proaktif untuk menjadikan pekerjaan lebih bermakna. Karyawan yang melakukan modifikasi pekerjaannya secara proaktif dapat mengoptimalkan kesesuaian antara pribadi dan pekerjaan. Konsekuensinya adalah pengalaman bekerja mereka menjadi bermakna (Tims, Derks, \& Bakker, 2016). Kemungkinan meaningful work menjadi mediator antara job crafting dan work engagement karyawan didukung hasil penelitian Fairlie (2011) yang menemukan meaningful work mampu memprediksi secara substantif varian work engagement karyawan, bahkan setelah mengendalikan karakteristik pekerjaan lainnya.

Mengacu hasil telaah teoretis yang sudah dipaparkan sebelumnya, maka penelitian ini mengusulkan model mediator meaningful work pada hubungan antara job crafting dengan work engagement. Hipotesis yang diajukan dalam penelitian ini adalah model teoretis work engagement karyawan generasi millennial yang bekerja di BUMN berdasarkan job crafting yang dimediasi oleh meaningful work akan sesuai dengan kondisi empiris.

\section{Metode}

Penelitian sekarang ini menggunakan pendekatan kuantitatif dengan fokus pada uji hipotesis yang sudah dirumuskan sebelumnya berdasarkan konstruksi teoretis. Penelitian melibatkan variabel work engagement, meaningful work dan job crafting. Variabel yang berfungsi sebagai variabel endogen dalam penelitian ini yaitu work engagement; sedangkan variabel eksogen yaitu job crafting. Variabel meaningful work merupakan variabel perantara yang didalam SEM dikategorikan sebagai variabel endogen. Jadi suatu variabel yang memberikan efek terhadap variabel endogen namun mendapatkan efek dari variabel eksogen dikategorikan sebagai variabel endogen (Ghozali, 2011). Meaningful work dalam penelitian ini selain memberikan efek terhadap variabel work engagement, juga mendapatkan efek dari variabel job crafting. Instrumen yang digunakan untuk mengumpulkan data adalah: Utrecht Work Engagement Scale (Bakker \& Schaufeli, 2010; Schaufeli et al., 2006), Skala Job Crafting (Tims, Bakker, \& Derks, 2012) dan Skala Meaningful Work (Lips-Wiersma \& Wright, 2012). Prosedur pengambilan data dilakukan menggunakan Google Form dengan pertimbangan generasi millenial lebih tertarik jika pengisian skala menggunakan gawai (gadget).

Model analisis dalam penelitian ini menggunakan Structural Equation Modeling (SEM) Full Model dengan mediator. Sebuah model dikatakan sebagai Model Penuh (Full Model) jika di dalamnya terdapat model pengukuran dan model struktural.

Uji kecocokan model untuk menyatakan suatu model dikatakan fit atau tidak, dilakukan pengujian kecocokan (goodness of fit). Ada beberapa parameter yang dapat digunakan sebagai dasar untuk uji kecocokan model. Dalam penelitian ini parameter yang akan digunakan berdasar nilai CMIN/DF, CFI, AGFI, GFI dan RMSEA. Suatu model dinyatakan fit atau layak jika minimal salah satu kriteria tersebut terpenuhi. Model dinilai lebih baik apabila dapat memenuhi lebih dari satu parameter fit . 
Hasil uji normalitas menunjukkan data penelitian memiliki nilai critical values skewness atau kurtosis di luar area -2,58 sampai dengan 2,58 (Ghozali, 2011), yaitu nilai ratio kritis sebesar 42.27. Artinya sebaran data penelitian tidak normal sehingga analisis model dilakukan dengan metode estimasi GLS (Generalized Least Square).

Terkait dengan uji model, pada penelitian ini akan dianalisis model mediasi meaningful work antara job crafting dengan work engagement. Model akan diuji untuk mendapatkan model yang fit (sesuai kondisi empiris). Metode estimasi untuk melihat efek mediasi, yaitu dengan menggunakan metode Bootstrap Biascorrected Confidence Interval 95\%. Apabila nilai efek tidak langsung signifikan dan nilai Confidence Interval (CI) yang dihasilkan tidak mengandung zero (nol); dikatakan terjadi efek mediasi (Preacher \& Hayes, 2008; Shrout \& Bolger, 2002).

\section{Hasil}

Responden penelitian adalah karyawan generasi millennial yaitu mereka yang lahir antara tahun 1980-2000 ( $\mathrm{N}=381)$. Responden laki-laki lebih banyak dibandingkan perempuan yaitu sebesar $62,20 \%$. Tingkat pendidikan terbesar didominasi oleh sarjana strata satu $(67,19 \%)$ dan berstatus menikah $(69,03 \%)$.

Domisili responden tersebar mulai dari pulau Sumatra sampai ke Papua. Masa kerja responden minimal 2 tahun dan maksimal 16 tahun dengan rerata masa kerja sebesar 6,9 tahun. Persentase terbesar penghasilan tahunan pada kisaran Rp. 65.000.000,- sampai Rp. 120.000.000,sebesar 32,55\%. Sebaran responden berdasarkan jenis kelamin, tingkat pendidikan, status pernikahan, masa kerja dan nominal penghasilan tahunan ditampilkan pada tabel 1 .

Tabel 1.

Sebaran Responden Penelitian

\begin{tabular}{llrrrr}
\hline Karakteristik & Kelompok & Jumlah & \multicolumn{1}{c}{$\%$} & Total & $\%$ \\
\hline Jenis Kelamin & Laki-laki & 237 & 62,20 & 381 & 100 \\
& Perempuan & 144 & 37,80 & & \\
Tingkat & SLTA/Sederajat & 11 & 2,89 & & \\
Pendidikan & Diploma & 49 & 12,86 & 381 & 100 \\
& Strata 1 & 256 & 67,19 & & \\
Status & Strata 2 & 65 & 17,06 & & \\
Pernikahan & Tidak Menikah & 118 & 30,97 & 381 & 100 \\
Penghasilan & Menikah & 263 & 69,03 & & \\
Tahunan (dalam & Di bawah Rp. 65.000 & 62 & 16,27 & & \\
ribuan rupiah) & 65.000 -- 120.000 & 124 & 32,55 & & \\
& $121.000,--180.000$ & 88 & 23,10 & & \\
& $181.000,--240.000$ & 44 & 11,55 & 381 & 100 \\
& $241.000,-300.000$ & 29 & 7,61 & & \\
& $301.000-360.000$ & 10 & 2,62 & & \\
& Di atas 361.000 & 24 & 6,30 & & \\
Masa Kerja & $>$ 5 tahun & 207 & 54,33 & 381 & 100 \\
& $<=5$ tahun & 174 & 45,67 & & \\
\hline
\end{tabular}


Kategorisasi data penelitian dilakukan dengan menggunakan data empirik. Data dikelompokan menjadi 5 kategori, yaitu sangat rendah, rendah, sedang, tinggi dan sangat tinggi dengan menggunakan rumus persentil. Data deskriptif menunjukkan bahwa secara umum work engagement responden ada pada kategori sedang $($ mean $=54,58)$ dan secara khusus, persentase tertinggi ada di kategori rendah (31,76\%).

Asumsi pertama untuk menggunakan teknik analisis data dengan SEM adalah jumlah responden minimal 200 sudah terpenuhi. Asumsi kedua adalah antar variabel penelitian memiliki korelasi yang sesuai dengan konsep teoritis yang digunakan terpenuhi. Meaningful work berkorelasi secara positif dengan work engagement $(\mathrm{r}=0.73 ; \mathrm{p}=0.00), \quad$ job crafting dengan meaningful work $(\mathrm{r}=0,68 ; \mathrm{p}=0.00)$ dan job crating berkorelasi dengan work engagement ( $r=0,67 ; p=0.00)$.

Kategorisasi data penelitian dilakukan dengan menggunakan data empirik. Data dikelompokan menjadi 5 kategori, yaitu sangat rendah, rendah, sedang, tinggi dan sangat tinggi dengan menggunakan rumus persentil. Data deskriptif menunjukkan bahwa secara umum work engagement responden ada pada kategori sedang $($ mean $=54,58)$ dan secara lebih rinci, persentase tertinggi berada pada kategori rendah (31,76\%).

Asumsi pertama untuk menggunakan teknik analisis data dengan SEM adalah jumlah responden minimal 200 sudah terpenuhi. Asumsi kedua adalah antar variabel penelitian memiliki korelasi yang sesuai dengan konsep teoritis yang digunakan terpenuhi. Meaningful work berkorelasi secara positif dengan work engagement $(\mathrm{r}=0.73 ; \mathrm{p}=0.00)$, job crafting berkorelasi dengan meaningful work ( $\mathrm{r}=$ 0,$68 ; \mathrm{p}=0.00$ ) dan job crafting berkorelasi dengan work engagement $(\mathrm{r}=0,67 ; \mathrm{p}=0.00)$.

Instrumen yang digunakan untuk mengumpulkan data dikatakan memiliki konsistensi internal yang baik yang ditunjukkan dengan koefisien $\alpha$ Cronbach mendekati 1. Skala Work Engagement ( $\alpha$ $=0,194)$, Skala Meaningful Work $(\alpha=0,930)$ dan Skala Job Crafting $(\alpha=0,901)$ dikatakan reliabel sebagai alat ukur. Uji model pengukuran menunjukkan bahwa model fit dengan $\mathrm{CMIN} / \mathrm{df}=2,46(\leq 5.00), \mathrm{CFI}=$ $0,76(<0,90)$ dan RMSEA=0,06 $(\leq 0,08)$. Nilai muatan faktor dari setiap alat ukur berada di atas 0.4 kecuali aspek developing self untuk variabel meaningful work $(\lambda=0.15)$. Walaupun loading-nya kurang dari 0.4, tetapi secara masih signifikan.

Hasil uji model struktural menunjukkan bahwa model work engagement merupakan model yang fit. Kriteria fit memenuhi 4 dari 5 parameter yang digunakan. yaitu $\mathrm{CMIN} / \mathrm{DF}=2.46$ $(\leq 5,00)$, RMSEA $=0,06(\leq 0.08)$, GFI $=0.938(\geq$ $0,9)$ dan AGFI=0, $909(\geq 0,9)$. Artinya model teoritis work engagement untuk generasi millennial yang bekerja di BUMN sesuai dengan kondisi empiris. Hasil uji model mediasi work engagement generasi millennial yang bekerja di BUMN secara visual ditampilkan pada Gambar 1.

Hasil uji mediasi antara job crafting dan work engagement menunjukkan bahwa meaningful work berperan sebagai mediator untuk hubungan job crafting dengan work engagement. Pengaruh langsung job crafting terhadap work engagement menunjukkan hasil yang signifikan dengan nilai $\beta$ sebesar 0,22 . Pengaruh tidak langsung job crafting terhadap work engagement melalui meaningful work juga menunjukkan hasil yang signifikan dengan nilai $\beta=0,69$. 


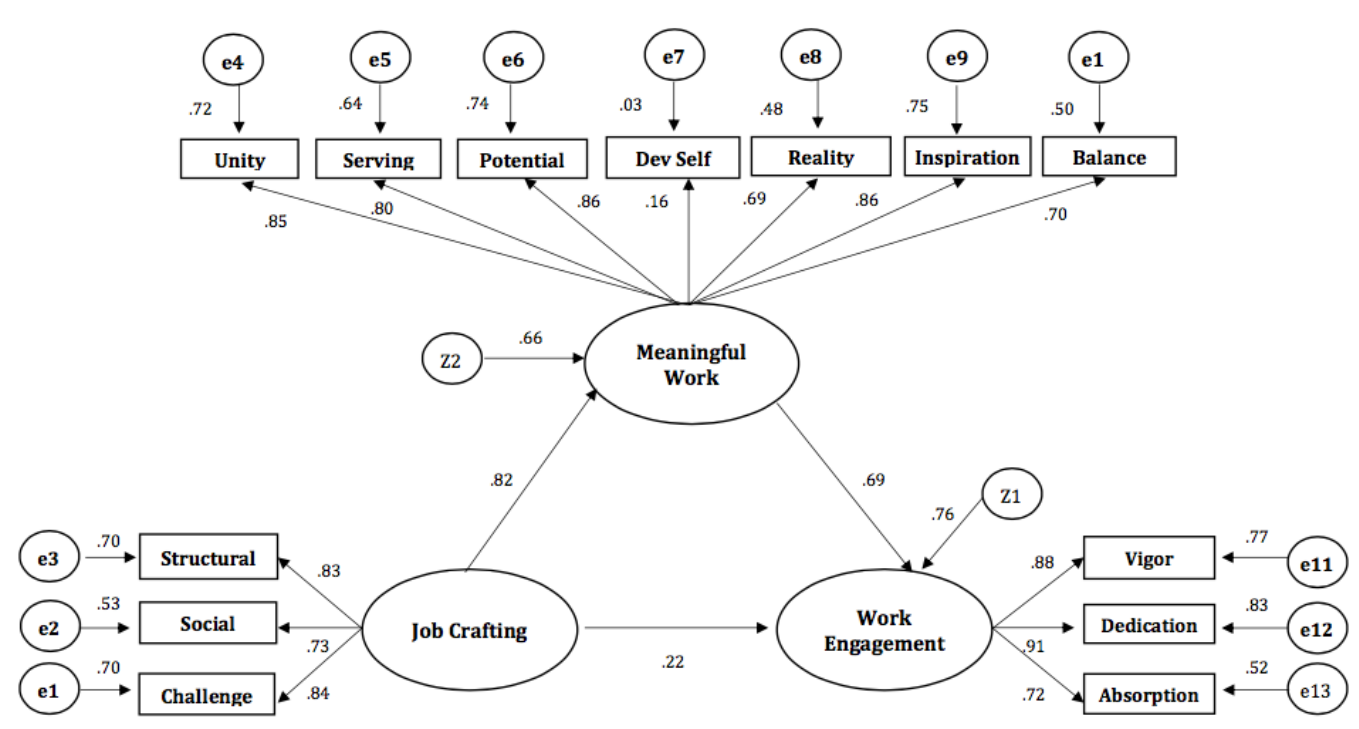

Gambar 1. Model mediasi work engagement generasi millennial yang bekerja di

Artinya job crafting memberikan pengaruh yang lebih kuat terhadap work engagement jika melalui meaningful work dibandingkan ketika dihubungkan secara langsung. Tujuan penelitian yang ingin mendapatkan dukungan empirik untuk model mediasi work engagement pada angkatan kerja generasi millennial terbukti secara empiris.

\section{Diskusi}

Meaningful work pada karyawan generasi millennial yang bekerja di BUMN menjadi perantara hubungan positif antara job crafting dengan work engagement. Pekerjaan yang memberi peluang bagi karyawan angkatan kerja generasi millennial untuk melakukan rekayasa, dapat memunculkan perasaan atau pemikiran bahwa pekerjaannya bermakna, yang kemudian berpengaruh pada tingginya work engagement.

Pentingnya meaningful work untuk meningkatkan work engagement angkatan kerja generasi millennial sejalan dengan penelitian-penelitian sebelumnya
(Albrecht, 2013; Geldenhuys, Łaba, \& Venter, 2014; Hoole \& Bonnema, 2015). Ketika kebutuhan fundamental individu untuk memiliki meaningful work terpenuhi maka sangat logis hal tersebut berdampak positif terhadap keterlibatan mereka dalam pekerjaan. Meaningful work menjadi sumber daya pekerjaan (job resources) karena meaningful work menstimulasi a sense of comprehension yaitu pemahaman tentang peran seseorang dalam organisasi (Steger \& Dik, 2010) dan karenanya menghasilkan dampak positif terhadap work engagement.

Karyawan dengan pemahaman jelas tentang kekuatan diri, tujuan dan kontribusi pribadinya, menurut Kahn (1990) memiliki kecenderungan untuk menginvestasikan diri mereka secara fisik, mental dan emosional ke dalam tugastugas dalam pekerjaan mereka. Karyawan yang menilai bahwa pekerjaannya bermakna secara fisik maupun mental akan bersemangat dalam mengerjakan tugas (vigor), merasa mudah fokus dan menemukan keasyikan pada penyelesaian tugas (absorption) sekaligus memicu 
antusiasme, inspirasi, dan kebanggaan (dedication) terhadap pekerjaannya.

Work engagement menjadi sebuah konsekuensi dari meaningful work karena pekerjaan bermakna menyalakan api dalam diri setiap karyawan yang mengarah pada level work engagement yang lebih tinggi. Meaningful work digambarkan sebagai potensi motivasional dalam meningkatkan work engagement karyawan (May et al., 2004; Wingerden \& Stoep, 2017).

Organisasi menurut Walsh dan Volini (2017) mengakui bahwa instrumen penting untuk mempertahankan karyawan serta meningkatkan keterlibatan mereka dalam pekerjaan adalah dengan mengembangkan meaningful work.

Setiap organisasi memiliki kapasitas untuk menumbuhkembangkan pekerjaan bermakna dengan mengimplementasikan beragam praktik untuk menciptakan lingkungan kerja yang memiliki arti khusus bagi individu (Pratt, Pradies, \& Lepisto, 2013). Pentingnya lingkungan kerja yang bermakna untuk meningkatkan keterikatan kerja sejalan dengan karakteristik angkatan kerja generasi millennial di mana mereka menginginkan adanya tujuan dan mampu berkontribusi secara langsung terhadap perusahaan ketika mereka bekerja (Holmberg-Wright, Hribar, \& Tsegai, 2017; Lee, 2017; Weeks, 2017).

Mereka juga bersedia untuk bekerja melampaui tuntutan pekerjaan mereka dalam membantu kesuksesan organisasi sekaligus mencari peluang profesional untuk menciptakan perbedaan yang berdampak positif terhadap organisasi (DeVaney, 2015; Gayle, 2019; Trombitas \& Hoover, 2015). Karakteristik lainnya adalah mereka menempatkan nilai-nilai kerja ekstrinsik lebih tinggi dibandingkan nilai kerja intrinsik, berorientasi sosialaltruistik, dan masih mempertimbangkan faktor gengsi (prestige) ketika membuat keputusan terkait pekerjaan (Kuron, Lyons, Schweitzer \& Ng, 2015).

Angkatan kerja generasi millennial peduli dengan pekerjaan mereka, berupaya menemukan kebermaknaan kerja dan memiliki dorongan kuat untuk terlibat dalam tugas-tugas yang memiliki makna bagi mereka meskipun tidak ada dukungan yang memadai pengembangan diri mereka (Nooraddini, Ton, \& Sherehiy, 2016). Selain pekerjaan bermakna, generasi millennial juga menginginkan pekerjaan yang memberikan cukup tantangan, pekerjaan yang menyediakan peluang untuk belajar yang dapat mendukung kemajuan karir mereka (Dries, Pepermans dan De Kerpel, 2008).

Rawlins, Indvik dan Johnson (2008) menemukan angkatan kerja generasi millennial menempatkan meaningful work lebih penting dibandingkan upah finansial. Bagi mereka tantangan dalam pekerjaan dan peluang belajar yang luas sumber motivasi intrinsik yang dapat mereduksi relevansi permasalahan jangka pendek seperti gaji sekaligus meningkatkan kesediaan berkontribusi pada konteks yang lebih luas. Job crafting berkontribusi lebih kuat terhadap tingkat work engagement karyawan millennial melalui meaningful work dibandingkan pengaruhnya secara langsung. Jadi untuk mendorong setiap individu bergerak melampaui pemenuhan kebutuhan dasar mereka adalah dengan membangun rasa kebermaknaan dalam bekerja dengan membuka peluang untuk melakukan rekayasa dalam pekerjaan mereka (Lysova, Allan, Dik, Duffy, \& Steger, 2019). 
Rekayasa pekerjaan merupakan sebuah pola pikir di mana karyawan secara proaktif mendefinisikan kembali desain pekerjaannya. Pola pikir ini menempatkan karyawan pada posisi sebagai pengemudi kendaraan yang memiliki kendali penuh atas kendaraannya. Individu yang percaya bahwa dirinya memiliki kendali atas nasibnya sendiri (self-determination) berpeluang besar untuk mengalami pekerjaan bermakna. Ketika kendali ada pada dirinya, maka individu akan membangun batasan-batasan untuk pekerjaan mereka yang selaras dengan preferensinya. Saat keselarasan terjadi antara tuntutan pekerjaan dengan preferensi pribadi, maka rasa kebermaknaan dalam pekerjaan akan dialami oleh individu tersebut (Berg, Dutton \& Wrzesniewski, 2013; Wrzesniewski \& Dutton, 2001).

Rasa kebermaknaan akan terbangun lebih kuat ketika dalam melakukan rekayasa pekerjaan, mereka secara proaktif memodifikasi tuntutan kerja dan sumberdaya yang ada, menciptakan tantangan baru dalam pekerjaan (Petrou, Bakker, \& van den Heuvel, 2017), membangun hubungan lebih positif dengan orang lain dan mengubah cara pandang (mindset) agar pekerjaan yang mereka lakukan dapat menciptakan manfaat yang lebih banyak untuk orang lain (Grant et al., 2007). Melalui kombinasi perubahan tersebut, mereka menjadi pelaku rekayasa pekerjaan yang berdampak lebih luas pada lingkungan kerja maupun pihak lain yang terlibat di dalam pekerjaan tersebut. Perasaan bermakna dalam pekerjaan berkembang ketika manfaat yang dihasilkan lebih besar dan berdampak lebih luas.
Rekayasa pekerjaan, menurut Wrzesniewski, Berg dan Dutton (2010), menjadi sangat penting sebagai sebuah jalan menuju meaningful work dalam konteks dunia kerja modern. Perubahan global terkait desain kerja yang awalnya berorientasi ekonomi berbasis manufaktur ke arah ekonomi berbasis layanan dan pengetahuan menuntut organisasi untuk melakukan penyesuaian dalam membuat rancangan kerja. Grant dan Ashford (2008) menyarankan organisasi menggunakan perspektif proaktif dalam membuat rancangan kerja. Perspektif proaktif ditandai dengan makin pentingnya karyawan mengambil inisiatif dalam mengantisipasi dan menciptakan perubahan dalam cara kerja. Perspektif ini didasari oleh makin dinamisnya pekerjaan dan semakin tingginya tingkat ketidakpastian. Pendapat ini didukung oleh Frese dan Fay (2001) yang menyatakan bahwa organisasi akan mendapatkan keuntungan yang sangat besar dengan mendorong karyawannya untuk melakukan inovasi dan beradaptasi.

Ciri utama rekayasa pekerjaan adalah karyawan secara proaktif melakukan perubahan-perubahan dalam pekerjaan mereka. Karyawan menggunakan pengetahuan unik terkait pekerjaan mereka dan karakteristik pribadi dalam melakukan modifikasi dalam pekerjaan mereka dengan cara-cara yang lebih bermakna. Kebebasan untuk mengambil insiatif membuka banyak peluang bagi setiap karyawan untuk menghasilkan pengalaman-pengalaman bermakna melalui rekayasa pekerjaan.

\section{Kesimpulan}


Usulan ekstensi Model JD-R spesifik pada sampel angkatan kerja generasi millennial terverifikasi secara memuaskan karena mampu menjelaskan lebih dari 78,5\% variabilitas work engagement mereka. Perluasan Model JD-R dengan menawarkan meaningful work sebagai mekanisme psikologis dapat menjelaskan bagaimana dan mengapa pengalaman terkait sumber daya pribadi, sumber daya kerja berakibat pada peningkatan work engagement karyawan generasi millennial. Hal ini menjelaskan proses-proses psikologis yang diasumsikan mendasari hubungan antara sumber daya kerja, sumber daya pribadi dan work engagement. Penelitian sekarang mengkonfirmasikan temuan-temuan penelitian terdahulu tentang pentingnya dan besarnya pengaruh (langsung) pekerjaan bermakna terhadap work engagement angkatan kerja generasi millennial. Penelitian sekarang menemukan job crafting sebagai prediktor yang paling kuat pengaruhnya. Sebagai prediktor, job crafting menjadi faktor kunci ketika organisasi bermaksud meningkatkan work engagement angkatan kerja generasi millennial.

\section{Saran}

Job crafting memiliki peran yang signifikan dalam menumbuhkan meaningful work karyawan generasi millennial. Saran-saran yang dapat dilakukan untuk perusahaan yang tenaga kerjanya didominasi oleh generasi millennial adalah: 1) Melakukan pemetaan passion dari karyawan millennial lalu memberikan kesempatan luas kepada mereka untuk dapat mengembangkan diri dan menyelesaikan pekerjaan mereka dengan cara-cara baru yang lebih kreatif dan inovatif sesuai dengan kapasitas mereka sehingga dapat menciptakan engagement yang lebih tinggi pada pekerjaannya, 2) Membuat programprogram untuk menyelaraskan misi personal karyawan millennial dengan misi organisasi dan pekerjaannya sehingga para karyawan millennial dapat mengalami perasaan bermakna dalam bekerja, yang pada gilirannya akan mampu mempertahankan bahkan meningkatkan work engagement-nya, 3) Membudayakan kompetisi terkait inovasi kerja sebagai salah satu strategi menstimulasi job crafting karyawan generasi millennial. Kompetisi inovasi kerja yang disertai dengan pengakuan (acknowledgment) atas pencapaian kinerja tersebut dapat memunculkan perasaan bermakna terkait pekerjaannya dan berimplikasi pada engagement mereka

\section{Kepustakaan}

Akhavan Sarraf, A. R., Abzari, M., Nasr Isfahani, A., \& Fathi, S. (2017). Generational differences in job engagement: A case study of an industrial organization in Iran. Industrial and Commercial Training, 49(3), 106-115. doi: $\underline{10.1108 / \text { ICT-10- }}$ 2016-0068

Albrecht, S. L. (2013). Work engagement and the positive power of meaningful work. Advances in Positive Organizational Psychology, 1(2002), 237-260. doi: 10.1108/S2046410X(2013)0000001013

Alexander, W. B., \& Mulyati, R. (2017). Hubungan antara motivasi kerja ekstrinsik dan keterikatan kerja pada karyawan Universitas Islam Indonesia. Manuskrip tidak dipublikasikan, Fakultas Psikologi dan Ilmu Sosial 
Budaya, Universitas Islam Indonesia, Yogyakarta.

Bakker, A. B. (2011). An evidence-based model of work engagement. Current Directions in Psychological Science, 20(4), 265-269. doi: 10.1177/0963721411414534

Bakker, A. B, \& Albrecht, S. (2018). Work engagement: Current trends. Career Development International, 23(1), 4-11. doi: 10.1108/CDI-11-2017-0207

Bakker, A. B, \& Demerouti, E. (2007). The Job Demands-Resources model: State of the art. Journal of Managerial Psychology, 22, pp. 309-328. doi: $\underline{10.1108 / 02683940710733115}$

Bakker, A. B, \& Demerouti, E. (2008). Towards a model of work engagement. Career Development International, 13(3), 209-223. doi: $\underline{10.1108 / 13620430810870476}$

Bakker, A. B., \& Demerouti, E. (2014). Job demands-resources theory. In P. Y. Chen \& C. L. Cooper (Eds.), Wellbeing: A complete reference guide. Work and wellbeing (pp. 37-64). : Wiley-Blackwell.

Bakker, A. B, \& Demerouti, E. (2017). Job demands-resources theory: Taking stock and looking forward. Journal of Occupational Health Psychology, 22(3), 273-285. doi: $10.1037 /$ ocp0000056

Bakker, A. B., \& Sanz-Vergel, A. I. (2013). Weekly work engagement and flourishing: The role of hindrance and challenge job demands. Journal of Vocational Behavior, 83(3), 397-409. doi: $\underline{10.1016 / j . j v b .2013 .06 .008}$

Bakker, A. B., \& Schaufeli, W. B. (2010). Defining and measuring work engagement: Bringing clarity to the concept. In A.B. Bakker (Ed), Work Engagement: A Handbook of Essential Theory and Research, (pp. 10-24). doi: 10.4324/9780203853047

Bakker, A. B., Albrecht, S. L., \& Leiter, M. P. (2011). Key questions regarding work engagement. European Journal of Work and Organizational Psychology, 20(1), 4-28. doi: 10.1080/1359432X.2010.485352

Berg, J. M., Dutton, J. E., \& Wrzesniewski, A. (2013). Job crafting and meaningful work. In B. J. Dik, Z. S. Byrne, \& M. F. Steger (Eds.), Purpose and meaning in the workplace (pp. 81104). Washington, DC: American Psychological Association.

Berg, J. M., Wrzesniewski, A., \& Dutton, J. E. (2010). Perceiving and responding to challenges in job crafting at different ranks: When proactivity requires adaptivity. Journal of Organizational Behavior, 31(2-3), 158186. doi: $10.1002 / j o b .645$

Chawla, D., Dokadia, A., \& Rai, S. (2017). Multigenerational differences in career preferences, reward preferences and work engagement among Indian employees. Global Business Review, 18(1), 181-197. doi: $\underline{10.1177 / 0972150916666964}$

Demerouti, E. (2014). Design your own job through job crafting. European Psychologist, 19(4), 237-243. doi: 10.1027/1016-9040/a000188

Demerouti, E., Bakker, A. B., Nachreiner, F., \& Schaufeli, W. B. (2001). The job demands-resources model of burnout. Journal of Applied Psychology, 86(3), 499-512. doi: 10.1037/0021$\underline{9010.86 .3 .499}$

DeVaney, S. A. (2015). Understanding the millennial generation. Journal of Financial Service Professionals, 69(6), 11-14. Diunduh dari http://eds.a.ebscohost.com.laureatec h.idm.oclc.org/eds/pdfviewer/pdfvie wer?sid=0a0336d0-b8da-410d-a5b37e42fa4cbe86@sessionmgr4004\&vid= $\underline{1 \& \text { hid }=4210}$

Dries, N., Pepermans, R., \& De Kerpel, E. (2008). Exploring four generations' beliefs about career: Is satisfied the 
new successful? Managerial Psychology, 23(8), 907-928. doi: 10.1108/MBE-09-2016-0047

Fairlie, P. (2011). Meaningful work, employee engagement, and other key employee outcomes: Implications for human resource development. Advances in Developing Human Resources, 13(4), 508-525. doi: 10.1177/1523422311431679

Frese, M., \& Fay, D. (2001). Personal initiative: An active performance concept for work in the 21st century. Research in Organizational Behavior, 23, 133-187. doi: 10.1016/S01913085(01)23005-6

Gayle, L. (2019). 7 Millennial-inspired ways to improve your workplace. Diunduh dari

https://www.hrexchangenetwork.co m/employee-engagement/articles/7millennial-inspired-ways-toimprove-your-workplace

Geldenhuys, M., Łaba, K., \& Venter, C. M. (2014). Meaningful work, work engagement and organizational commitment. SA Journal of Industrial Psychology, 40(1), 1-10. doi: 10.4102/sajip.v40i1.1098

Ghozali, I. (2011). Model persamaan struktural: Konsep dan aplikasi dengan program AMOS 24 (Edisi 7). Semarang: Badan Penerbit Universitas Diponegoro.

Grant, A. M., \& Ashford, S. J. (2008). The dynamics of proactivity at work. Research in Organizational Behavior, 28, 3-34. doi: 10.1016/j.riob.2008.04.002

Grant, A. M., Campbell, E. M., Chen, G., Cottone, K., Lapedis, D., \& Lee, K. (2007). Impact and the art of motivation maintenance: The effects of contact with beneficiaries on persistence behavior. Organizational Behavior and Human Decision
Processes, 103, 53-67. doi: 10.1016/j.obhdp.2006.05.004

Grant, A. M., Fried, Y., \& Juillerat, T. (2010). Work matters: Job design in classic and contemporary perspectives. In $\mathrm{S}$. Zedeck (Ed.), APA Handbook of industrial and organizational psychology (pp. 417-453). Washington, DC: American Psychological Association.

Hackman, J. R., \& Oldham, G. R. (1976). Motivation through the design of work: Test a theory. Organizational Behavior and Human Performance, 16, 250-279. doi: 10.1016/00305073(76)90016-7

Holmberg-Wright, K., Hribar, T., \& Tsegai, J. D. (2017). More than money: Business strategies to engage Millennials. Business Education Innovation Journal, 9(2), 14-23. Diunduh dari http://www.beijournal.com/images/ 2 V9N2 final 2-2.pdf

Hoole, C., \& Bonnema, J. (2015). Work engagement and meaningful work across generational cohorts. $S A$ Journal of Human Resource Management, 13(1), 1-11. doi: 10.4102/sajhrm.v13i1.681

Kahn, W. A. (1990). Psychological conditions of personal engagement and disengagement at work. Academy of Management Journal, 33(4), 692-724. doi: $\underline{10.5465 / 256287}$

Kiiru-Weatherly, P. (2016). Multigenerational workforce: Relationship between generational cohorts and employee engagement (Disertasi doktoral). Diunduh dari ProQuest Dissertations and Theses database. (UMI No. 10254108)

Kira, M., \& Balkin, D. B. (2014). Interactions between work and identities: Thriving, withering, or redefining the self? Human Resource Management 
Review, 24(2), 131-143. doi: 10.1016/j.hrmr.2013.10.001

Kuron, L., Lyons, S., Schweitzer, L., \& Ng, E. S. (2015). Millennials' work values: Differences across the school to work transition. Personnel Review, 44(6), 991-1009. doi: 10.1108/PR-01-20140024

Leana, C., Appelbaum, E., \& Shevchuk, I. (2009). Work process and quality of care in early childhood education: The role of job crafting. Academy of Management Journal, 52(6), 1169-1192. doi: 10.5465/AMJ.2009.47084651

Lee, D. (2017). Millennials and meaningfulness at work (Disertasi doktoral). Diunduh dari ProQuest Dissertations Publishing. (UMI No. 10605489)

Lewis, P. N., \& Yeoman, R. (2016). Busting the millennial myth-the power of purpose: An inquiry into the millennial generation's attitude towards working in employeeowned businesses and how they can prosper in millennials' hands. Diunduh dari http://www.fieldfisher.com/media/4 948679/eo-millennia web.pdf

Lips-Wiersma, M., \& Wright, S. (2012). Measuring the meaning of meaningful work: Development and validation of the Comprehensive Meaningful Work Scale (CMWS). Group and Organization Management, 37(5), 655-685. doi: $\underline{10.1177 / 1059601112461578}$

Lysova, E. I., Allan, B. A., Dik, B. J., Duffy, R. D., \& Steger, M. F. (2019). Fostering meaningful work in organizations: A multi-level review and integration. Journal of Vocational Behavior, 110, 374-389. doi: 10.1016/j.jvb.2018.07.004

May, D. R., Gilson, R. L., \& Harter, L. M. (2004). The psychological conditions of meaningfulness, safety and availability and the engagement of the human spirit at work. Journal of Occupational and Organizational Psychology, 77, 11-37. doi: 10.1348/096317904322915892.

Mulyati, R., Himam, F., Riyono, B., \& Suhariadi, F. (2018). Model regresi keterlibatan kerja tenaga kerja millennial. Manuskrip tidak dipublikasikan, Fakultas Psikologi dan Ilmu Sosial Budaya, Universitas Islam Indonesia, Yogyakarta.

Munfaridah, S., Mulyati, R., \& Kurniawan, I. (2018). Job crafting sebagai prediktor work engagement pada generasi millennial: Studi pada konsultan independen bidang perawatan kulit. Books of Abstract. Kongres XIII HIMPSI. Bandung, Indonesia.

Nakamura, S., \& Otsuka, Y. (2012). Job resources enhance work engagement through positive affect and meaningful work among Japanese employees. In F. Sarraci (Ed.), Psychology of emotions, motivations and actions. The happiness compass: Theories, actions and perspectives for well-being (pp. 141-151). Hauppauge, NY, US: Nova Science Publishers.

Nooraddini, I., Ton, A.-T., \& Sherehiy, B. (2016). Millennial work engagement: An unmet desire. Diunduh dari https://www.eurekafacts.com/ phocadownload/WhitePapers/Mille nnialWork Engagement.pdf

Parker, S. K., \& Collins, C. G. (2010). Taking stock: Integrating and differentiating multiple proactive behaviors. Journal of Management, 36(3), 633-662. doi: 10.1177/0149206308321554.

Petrou, P., Bakker, A. B., \& van den Heuvel, M. (2017). Weekly job crafting and leisure crafting: Implications for meaning-making and work engagement. Journal of Occupational and Organizational Psychology, 90(2), 129-152. doi: $\underline{10.1111 / j o o p .12160}$ 
Pratt, M. G., Pradies, C., \& Lepisto, D. A. (2013). Doing well, doing good, and doing with: Organizational practices for effectively cultivating meaningful work. In Bryan J Dik, Z. S. Byrne, \& M. F. Steger (Eds.), Purpose and meaning in the workplace. (pp. 173196). doi: $10.1037 / 14183-009$

Preacher, K. J., \& Hayes, A. F. (2008). Asymptotic and resampling strategies for assessing and comparing indirect effects in multiple mediator models. Behavior Research Methods, 40(3), 879 - 891. doi: 10.3758/BRM.403.879

Rawlins, C., Indvik, J., \& Johnson, P. R. (2008). Understanding the new generation: What the millennial cohort absolutely, positively must have at work. Journal of Organizational Culture, Communications and Conflict, 12(2), 19.

Rigoni, B., \& Nelson, B. (2016). Few millennials are engaged at work. Diunduh dari http://news.gallup.com/businessjour nal/195209/few-millennials-engagedwork.aspx?version=print

Rothmann, S., \& Olivier, A. L. (2007). Antecedents of work engagement in a multinational company. South African Journal of Industrial Psychology, 33(3), 49-56. doi: 10.4102/sajip.v33i3.396

Ryan, R. M., \& Deci, E. L. (2000). Selfdetermination theory and the facilitation of intrinsic motivation, social development, and well-being. American Psychologist, 55(1), 68-78. doi: $10.1037 / 0003-066$ X.55.1.68

Schaufeli, W. B., Bakker, A. B., \& Salanova, M. (2006). The measurement of work engagement with a short questionnaire: A cross-national study. Educational and Psychological
Measurement, 66(4), 701-716. doi: $\underline{10.1177 / 0013164405282471}$

Shrout, P. E., \& Bolger, N. (2002). Mediation in experimental and nonexperimental studies: new procedures and recommendations. Psychological Methods, 7(4), 422 - 445. doi: $10.1037 / 1082-989 X .7 .4 .422$

Shuck, B., \& Rose, K. (2013). Reframing employee engagement within the context of meaning and purpose: Implications for HRD. Advances in Developing Human Resources, 15(4), 341-355.

doi: $\underline{10.1177 / 1523422313503235}$

Slemp, G. R., \& Vella-Brodrick, D. A. (2014). Optimising employee mental health: The relationship between intrinsic need satisfaction, job crafting, and employee well-being. Journal of Happiness Studies, 15(4), 957-977. doi: 10.1007/s10902-0139458-3

Steger, M. F. (2016). Creating meaning and purpose at work. In L. G. Oades, M. F. Steger, A. D. Fave and J. Passmore (Eds). The Wiley Blackwell Handbook of the Psychology of Positivity and Strengths-Based Approaches at Work, (pp. 60-81). New Jersey: WileyBlackwell.

Steger, M. F., \& Dik, B. J. (2010). Work as meaning: Individual and organizational benefits of engaging in meaningful work. In P. A. Linley, S. Harrington, \& N. Garcea (Eds.), Oxford library of psychology. Oxford handbook of positive psychology and work (pp. 131-142). New York: Oxford University Press.

Strauss, K., \& Parker, S. K. (2014). Effective and sustained proactivity in the workplace: A self-determination theory perspective. In M. Gagne (Ed.), The Oxford Handbook of Work Engagement, Motivation, and Self- 
Determination Theory (pp. 50-71). New York: Oxford University Press. Tadić, M., Bakker, A. B., \& Oerlemans, W. G. M. (2015). Challenge versus hindrance job demands and wellbeing: A diary study on the moderating role of job resources. Journal of Occupational and Organizational Psychology, 88(4), 702725. doi: $10.1111 /$ joop. 12094

Tims, M., \& Bakker, A. B. (2010). Job crafting: Towards a new model of individual job redesign. SA Journal of Industrial Psychology, 36(2), 1-9. doi: 10.4102/sajip.v36i2.841

Tims, M., Bakker, A. B., \& Derks, D. (2012). Development and validation of the job crafting scale. Journal of Vocational Behavior, 80(1), 173-186. doi: 10.1016/j.jvb.2011.05.009

Tims, M., Bakker, A. B., \& Derks, D. (2013). The impact of job crafting on job demands, job resources, and wellbeing. Journal of Occupational Health Psychology, 18(2), 230-240. doi: 10.1037/a0032141

Tims, M., Derks, D., \& Bakker, A. B. (2016). Job crafting and its relationships with person-job fit and meaningfulness: A three-wave study. Journal of Vocational Behavior, 92, 44-53. doi: 10.1016/j.jvb.2015.11.007

Trombitas, P., \& Hoover, S. (2015). Millenials in construction: Learning to engage a new workforce. FMI.

Walsh, B., \& Volini, E. (2017). Rewriting the rules for the digital age:
2017 Deloitte global human capital trends. Diunduh dari situs Deloitte: https://www2.deloitte.com/content/ dam/Deloitte/global/Documents/Hu manCapital/hc-2017-global-humancapital-trends-gx.pdf

Weeks, K. P. (2017). Every generation wants meaningful work: Thinks other age groups are in it for the money. Diunduh dari situs HBR: https://hbr.org/2017/07/everygeneration-wants-meaningful-workbut-thinks-other-age-groups-are-init-for-the-money

Wingerden, J. Van, \& Stoep, J. Van der. (2017). The role of meaningful work in employees' work-related and general well-being. International Journal of Human Resource Studies, 7(4), 23. doi: 10.5296/ijhrs.v7i4.11611

World Economic Forum. (2017). Realizing human potential in the fourth industrial revolution: An agenda for leaders to shape the future of education, gender and work. In World Economic Forum White Paper. Geneva.

Wrzesniewski, A., \& Dutton, J. E. (2001). Crafting a job: Revisioning employee as active crafters of their work. Academy of Management Review, 26(2), 179-201. doi: 10.5465/amr.2001.4378011

Wrzesniewski, A., Berg, J. M., \& Dutton, J. E. (2010). Managing yourself: Turn the job you have into the job you want. Harvard Business Review, (June), 114-117. 